Primljen / Received: 28.4.2014. Ispravljen / Corrected: 7.8.2014.

Prihvaćen / Accepted: 26.8.2014. Dostupno online / Available online: 10.10.2014.

\section{Research on the length of passing distance in the real traffic flow}

\section{Authors:}

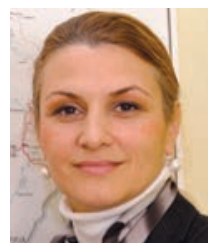

Biljana Ivanović, MSc. CE University of Montenegro Faculty of Civil Engineering in Podgorica biljanai@ac.me

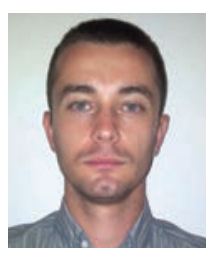

Nemanja Garunović, MSc. CE University of Novi Sad Faculty of Technical Sciences garunovic@uns.ac.rs

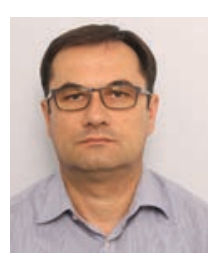

Prof. Zvonko Tomanović, PhD. CE University of Montenegro Faculty of Civil Engineering in Podgorica zvonko@ac.me

\section{Biljana Ivanović, Nemanja Garunović \& Zvonko Tomanović}

Subject review

\section{Research on the length of passing distance in the real traffic flow}

This paper presents research and analysis of the length of passing distance in the real traffic flow on the sections of two-way two-lane roads. Values of passing sight distance recommended by road design rulebooks and recommendations are often not consistent with the length of passing distance which occurs in the real traffic flow. In the research conducted for this study, it was found that the passing distance in real traffic flow are significantly shorter than the values obtained by mathematical models.

\section{Key words:}

passing, passing distance, passing sight distance, design speed, level of service

Pregledni rad

Biljana Ivanović, Nemanja Garunović \& Zvonko Tomanović

\section{Istraživanje duljine puta pretjecanja u realnom prometnom toku}

U okviru rada provedeno je istraživanje i analiza duljine puta pretjecanja u realnom prometnom toku na dionicama dvosmjernih dvotračnih cesta. Na osnovi duljine puta pretjecanja definira se pretjecajna preglednost i zone zabranjenog pretjecanja. Preporučene vrijednosti pretjecajne preglednosti iz pravilnika i preporuka o projektiranju cesta često nisu usklađene s duljinom pretjecanja koja se ostvaruje u realnom prometnom toku. Istraživanjem koje je provedeno za potrebe ovog rada utvrđeno je da su duljine puta pretjecanja u realnom prometnom toku znatno kraće u odnosu na vrijednosti koje se dobivaju prema matematičkim modelima. Ključne riječi:

pretjecanje, put pretjecanja, preglednost, računska brzina, nivo usluge

Übersichtsarbeit

Biljana Ivanović, Nemanja Garunović \& Zvonko Tomanović

\section{Untersuchung der Länge des Überholwegs im wirklichen Verkehrsfluss}

Diese Arbeit befasst sich mit Erforschungen und Analysen der Länge des Überholwegs im wirklichen Verkehrsfluss auf Abschnitten zweispuriger Fahrbahnen in beiden Richtungen. Aufgrund der Länge des Überholwegs werden die Übersichtlichkeit beim Überholen und Überholverbotszonen definiert. Empfohlene Werte der Übersichtlichkeit beim Überholen nach Vorschriften und Regelwerken für den Entwurf von Straßen sind oftmals nicht im Einklang mit der Länge des Überholwegs im wirklichen Verkehrsfluss. Dieser Arbeit unterliegende Untersuchungen haben gezeigt, dass die Länge des Überholwegs im wirklichen Verkehrsfluss im Vergleich zu Werten, die auf mathematischen Modellen beruhen, bedeutend verkürzt ist.

Schlüsselwörter:

Überholen, Überholweg, Übersichtlichkeit, Entwurfsgeschwindigkeit, Leistungsniveau 


\section{Introduction}

About $60 \%$ of traffic fatalities in OECD countries occur on twolane two-way roads, which points to the need to examine specific technical components and solutions that are applied in the design of these roads [1]. The main difference in traffic operated on twolane two-way roads, as compared to other types of roads, is the passing manoeuvre during which the vehicle moves to the lane intended primarily for the movement of vehicles coming from the opposite direction. For this reason, passing is considered to be one of the most challenging and complex actions in road traffic during which drivers adjust movement of their vehicles based on the assessment of several technical parameters.

The need for a vehicle participating in a traffic flow to conduct the overtaking action is proportional to minimum distances between the vehicles queued in that traffic flow, and the very possibility of passing depends on the existence of an acceptable interval in the opposite-direction flow, sufficient for conducting a safe passing action [2]. Creating technical conditions for safe passing is one of main tasks in the design of two-lane two-way roads. For this reason, the quality of overall traffic conditions on twolane roads for two-way traffic largely depends on vehicle passing features [3]. The quality of traffic conditions on these roads is determined based on the percentage of queue driving and speed of queue driving, which largely depends on the percentage of allowed passing zones along the total length of the observed section [4]. The percentage of allowed passing zones on the road depends primarily on the passing sight distance characteristics [5]. According to the previously established models, the passing sight distance depends on the speed of the passing vehicle and the speed of the vehicle being overtaken i.e. on the difference between these two speeds [2]. In the process of calculating the passing sight distance, the values of these speeds largely depend on characteristics of the reference vehicle, which is constantly changing due to improvement of technical features of vehicles involved in the traffic flow. Since vehicle characteristics and their driving-dynamic capabilities are constantly improving, it may reasonably be expected that the behaviour of drivers performing passing actions will also change. Changes of technical characteristics of vehicles and drivers' behaviour affect the traffic flow and speed parameters, and hence the realistically required passing distance. According to the AASHTO model [2], the passing distance directly affects the required passing sight distance based on which the allowed passing zones are defined. When designing roads, the rulebooks data on the required passing sight distance, determined based on the design speed and speed difference between the passing vehicle and the overtaken vehicle, are used to determine the passing sight distance. The value of speed difference adopted in the calculation procedure affects the passing distance, and so different passing distance and sight distance values can be obtained for the same design speed [6-9]. In addition, it is known that very often vehicles, when overtaking, move at speeds greater than the design speed because of the restricted time and passing distance constraints.
By taking into account the passing distance realized under real traffic flow conditions, proper conditions for adjustment of real and projected traffic requirements can be created when defining the passing sight distance. For this reason, and in order to modify the procedure and optimize the passing distance, it is imperative to determine passing distance characteristics under the real flow of traffic, as well as the passing distance differences according to the models used in rulebooks.

\section{Models and standards for determining passing distance and passing sight distance}

In the passing sight distance determination models, the passing distance can be expressed as a function of difference in speed of the overtaking vehicles, or as a function of speed of the overtaken vehicles. One of the first procedures for determining the passing sight distance, based on the research from 1940s, is the American AASHTO model from 1954 [6]. Subsequent research on the passing sight distance was based on the established AASHTO criteria, and it resulted in creation of alternatives to the existing passing sight distance models. These alternatives were published in the 1984 edition of the AASHTO policy document [7]. Subsequent editions from 1990, 1994, 2001 and 2011 do not contain significant changes to the model for the calculation of passing sight distance.

Models based on the design speed and vehicle speed differences were used until 1990s in the SEE countries, including Montenegro, for determining the passing distance and the passing sight distance [10]. The passing sight distance was defined in the road design rulebooks and standards on the basis of these models $[6-9,11]$. Despite the fact that the model used for calculating the passing sight distance is the same, there are nevertheless differences in rulebooks when it comes to the required passing sight distance.

\subsection{Model for calculating passing distance in SEE countries}

The model described in [12] is based on the assumption that the passing vehicle has the same time to pass a longer distance than the overtaken vehicle. This zone consists of two main parts: path of the overtaken vehicle $B$ that is moving at speed $V_{B}$ and additional path of the passing vehicle $A$, which is the result of the difference in speeds $V_{A}-V_{B}$ (Figure 1$)$.

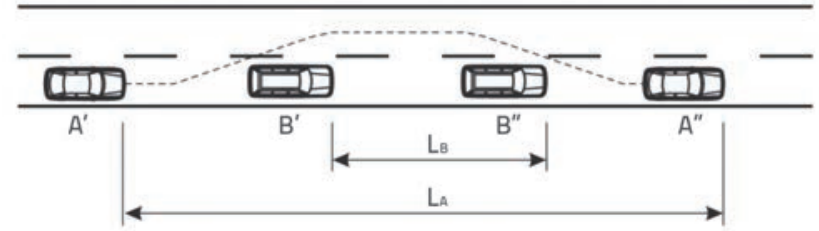

Figure 1. Elements of passing distance according to model accepted in SEE countries 
The passing distance $\left(P_{p}\right)$ can be calculated using the following mathematical relation:

$P_{p}=L_{A}=\frac{t}{3,6}\left(V_{r}+\Delta V\right)$

where:

$t$ - time needed to make the passing manoeuvre, [s]

$V_{r}$ - design speed, [km/h]

$\Delta V$ - difference in speed of the passed vehicle and passing vehicle, $[\mathrm{km} / \mathrm{h}]$.

According to this model, the speed of the overtaken vehicle is equal to the design speed of the road on which the overtaking is taking place, while the adopted speed of the passing vehicle is the speed that exceeds by $15 \mathrm{~km} / \mathrm{h}$ the speed of the overtaken vehicle, i.e., the difference in speed of the vehicles involved in the passing is $\Delta V=15 \mathrm{~km} / \mathrm{h}$ according to this model. Based on the research on which this model is based, the time $t=10$ $s$ is the time during which the passing vehicle can perform a normal passing manoeuvre and, therefore, this value has been adopted as relevant when designing the passing distance and the passing sight distance.

\subsection{AASHTO model}

According to the AASHTO model, the passing sight distance is expressed as the sum of the following distances [2]:

$\mathrm{PSD}=d_{1}+d_{2}+d_{3}+d_{4}$

where:

$d_{1}$ - distance travelled during perception and reaction time and during initial acceleration to the point of encroachment on the left lane

$d_{2}$ - distance travelled while the passing vehicle is at the left lane

$d_{3}$ - distance between the passing vehicle and the opposing vehicle at the end of the passing manoeuvre

$d_{4}$ - distance travelled by the opposing vehicle for two-thirds of the time the passing vehicle occupies the left lane.

According to the above mentioned model, the action of passing can be conducted in two phases as shown in Figure 2 . Since only the passing distance is presented here, the lengths relevant for further analysis are $d_{1}$ and $d_{2}$.

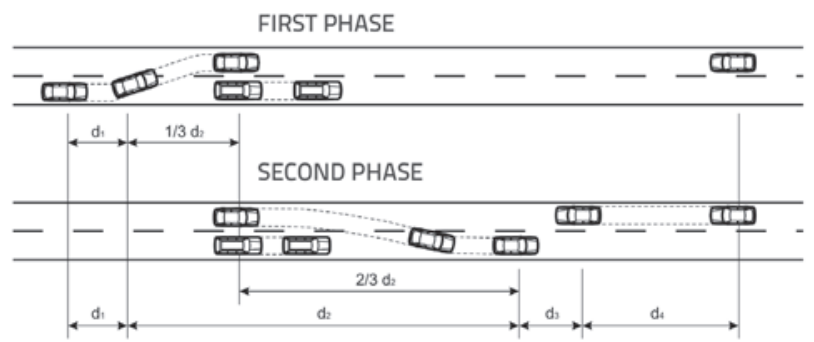

Figure 2. Elements of passing distance according to AASHTO model
According to the AASHTO model, the distance passed during the perception and reaction time and during the initial acceleration to the point of passing to the left lane is calculated as follows:

$d_{1}=0,278 \cdot t_{1} \cdot\left(v-m+\frac{a \cdot t_{1}}{2}\right)$

where:

$t_{1}$ - time of initial manoeuvre, [s]

$v$ - average speed of passing vehicle, $[\mathrm{km} / \mathrm{h}]$

$m$ - difference in speed of passed vehicle and passing vehicle, [km/h]

$a$ - average acceleration, [km/h/s].

The distance passed while the passing vehicle is in the left lane is calculated based on the following formula:

$d_{2}=0,278 \cdot v \cdot t_{2}$

where:

$t_{2}$ - time the passing vehicle occupies the left lane, [s].

\subsection{Wang and Cartmell model}

One of models for calculating the passing distance was developed by Wang and Cartmell [13]. According to this model, the passing distance is calculated as follows:

$P S D=X_{1}+X_{2}+X_{3}+C+V_{0} \cdot\left(T_{1}+T_{2}+T_{3}\right)$

where:

$X_{1}$ - distance travelled by the passed vehicle in Phase 1 in the $\mathrm{x}$-axis direction, $[\mathrm{m}]$

$X_{2}$ - distance travelled by the passed vehicle in Phase 2 in the $\mathrm{x}$-axis direction, [m]

$X_{3}$ - distance travelled by the passed vehicle in Phase 3 in the $x$-axis direction, [m]

$C$ - clearance between front bumpers of the passing and opposing vehicles at the end of the manoeuvre, [m]

$V_{0}$ - speed of vehicle coming from the opposite direction, [m/s]

$T_{1}$ - time for Phase 1, [s]

$T_{2}$ - time for Phase $2,[\mathrm{~s}]$

$T_{3}$ - time for Phase $3,[\mathrm{~s}]$.

In contrast to the above mentioned AASHTO model in which the passing occurs in two phases, in this model the passing is operated in three phases (Figure 3), as follows:

Phase 1: distance that the vehicle passes as of the moment it starts passing to the moment when it passes to the next lane parallel with the overtaken vehicle, so that the front edge of the passing vehicle and the rear edge of the overtaken vehicle are in the same plane;

Phase 2: distance that the vehicle passes as of the moment when the first phase finishes to the moment when the rear edge of the passing vehicle is in the same plane as the front edge of the overtaken vehicle; 
Phase 3: distance that the vehicle passes as of the moment when the second phase ends to the moment it returns to its own lane.

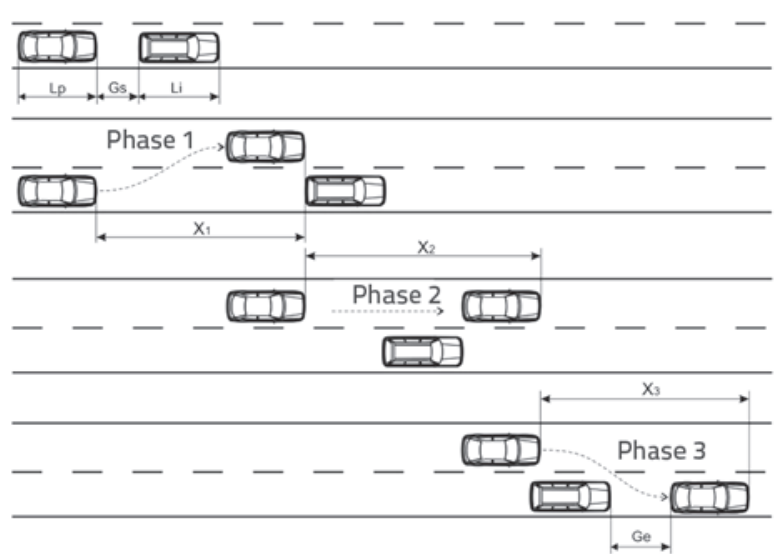

Figure3. Elements of passing distance according to Wang and Cartmell model

According to this model, the passing distance is described as the sum of lengths $X_{1}, X_{2}$ and $X_{3}$. These lengths depend on the distance between the vehicles at the start $\left(G_{s}\right)$ and the end of the passing distance $\left(G_{e}\right)$, the length of the passing vehicle $\left(L_{p}\right)$ and length of the overtaken vehicle $\left(L_{i}\right)$ and exclusively on the speed of the overtaken vehicle $\left(\mathrm{V}_{\mathrm{i}}\right)$, where it is considered that the speed of the passing vehicle can not exceed the maximum speed limit set for the section where the passing is conducted. The speed of the overtaken vehicle is adopted based on the model, and so for the design speed of $60 \mathrm{~km} / \mathrm{h}$, the speed of the overtaken vehicle $\left(V_{i}\right)$ is $51 \mathrm{~km} / \mathrm{h}$, for the design speed of $80 \mathrm{~km} / \mathrm{h}$, the speed of the overtaken vehicle is $65 \mathrm{~km} / \mathrm{h}$, etc. [13]. According to this model, the passing distance has the following analytical basis:

$L=L_{p}+L_{i}+G_{s}+G_{6}+V_{i} \cdot\left(T_{1}+T_{2}+T_{3}\right)$

\section{Methods and research locations}

Measurement of traffic flow parameters by analysing video recordings is one of the oldest and safest methods. The analysis of the traffic-flow video recordings was first conducted by Bob Grenshilds in the early 1930s. Current technology permits much better analysis of video recordings, which is why the methods for determining traffic flow parameters under different conditions are becoming increasingly accurate [14]. The study of traffic flow by analysis of video recordings according to the method described in [14-16] has proven to be highly efficient and accurate. This procedure is based on digital processing of video recordings using an appropriate software program. Namely, reference points or lines positioned at a known distance are added through software processing. In further analysis, the time in which vehicles pass through the reference lines is measured and the information is entered into the database, where the data are processed statistically. That is why this particular model was used in this research. Special quality of this method lies in the fact that participants in traffic flow are unaware that the traffic flow is recorded, and their behaviour is thus accurately represented. In order to analyse characteristics of passing, the following recordings of traffic flow were made in April and May 2013 on three sections of the road network in Montenegro:

- I section (Podgorica-Nikšić), 15, 17 and 18 April 2013

- II section (Podgorica-Cetinje), 27 and 29 April 2013

- III section (Danilovgrad-Nikšić), 14 and 15 May 2013.

SONYDCR-HC23, HANDYCAM $20 \mathrm{x}$ optical zoom with Carl Zeiss Lens with extra wide angle lens markings VCL-HA06 was used for recording.

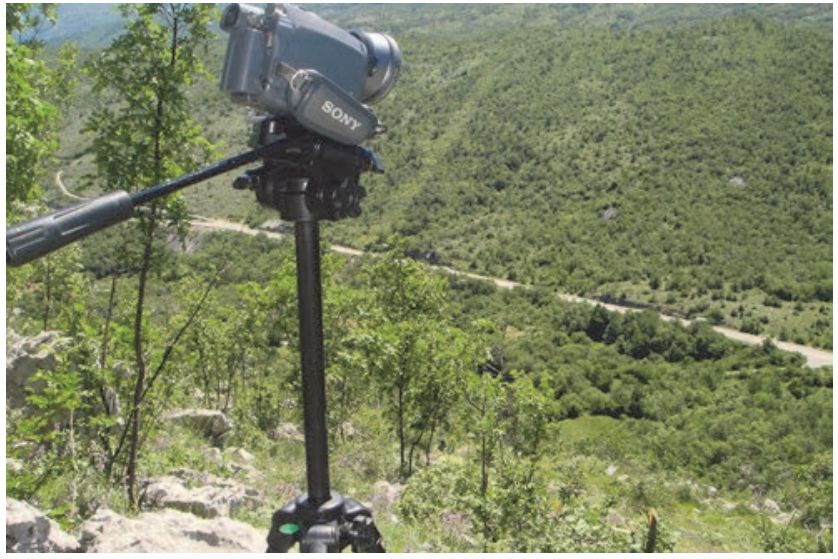

Figure 4. Position of cameras set for recording

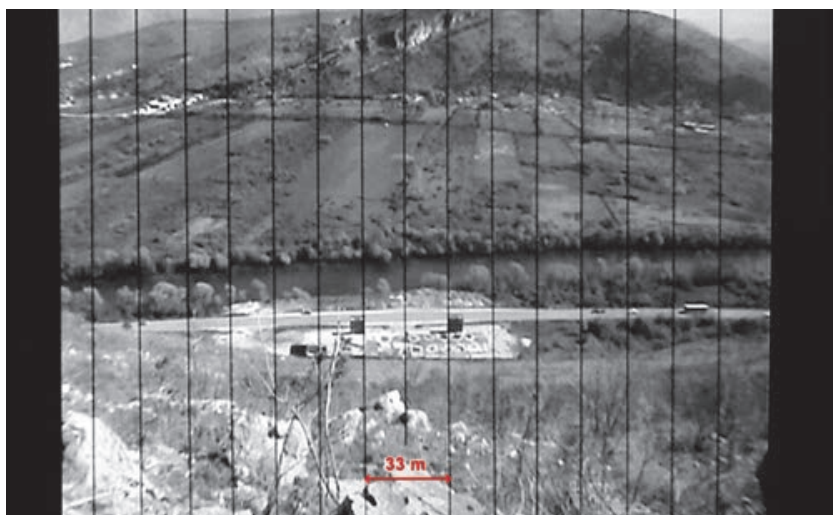

Figure 5. Video recording slide with defined reference lines

The analysis of real traffic video recordings made on three different sections of a two-lane road resulted in a sample of 203 passing actions for which characteristic parameters were established. The following software tools were used for the video recording and data analyses: Nero ShowTime, Adobe Premiere Pro 1.5, Microsoft Excel, and Minitab. The Nero ShowTime was used to view and analyse video recordings. The Adobe Premiere Pro 1.5 was used to process the video recordings, because video recording scan be slowed down and stopped with an error of 0.04 seconds, which provides high level 
of accuracy. This software also allows setting reference lines as a "layer" across the video recording. Reference lines were spaced at $16.5 \mathrm{~m}$ intervals, and then times of passing through these lines were registered.

The time data for vehicles passing through the reference lines were processed in Microsoft Excel, and then the values of passing parameters were determined by processing.

\subsection{Characteristics of sections on which research was conducted}

All sections belong to the A Category State Roads. They were selected based on their characteristics which provide conditions for different behaviour of drivers during the passing action. On the selected sections of two-lane two-way roads, the passing action is allowed on longer stretches, while other characteristics of longitudinal and transversal profiles provide for smooth passing. According to the density of traffic flow, these sections are characterized by medium load traffic, and the AADT is below 8,000 PC/day, while the share of commercial vehicles does not exceed12 \% (Records of the Transport Directorate of Montenegro from automatic traffic counters for 2013; the number of commercial vehicles is assumed).

\section{Section I}

This section is located at the trunk road Podgorica-Niksic, as shown in Figure 6. The road is in the horizontal curve with the radius of $2,500 \mathrm{~m}$, while the angle between tangents is $2^{\circ}$. The longitudinal grade is $0.5 \%$, and so the road can be considered flat, i.e. without longitudinal inclination. The roadway width is $2 \times 3.75+2 \times 0.5 \mathrm{~m}$. The shoulder (berm) is $1.5 \mathrm{~m}$ in width. The road surface is in good condition, without hair cracks. The road is in a cutting, but the slope is not close to the road. In this way, a plateau is formed next to the road, with an unused warehouse. An additional lane for the right turn from the Niksic-Podgorica direction is not operational. The total length of broken line is 600 $\mathrm{m}$ at this section. Before and after this section, the road runs in straight line, and the longitudinal grade is unchanged. The length of the first section road zone covered by the analysed video recording is $L=250 \mathrm{~m}$ [17].

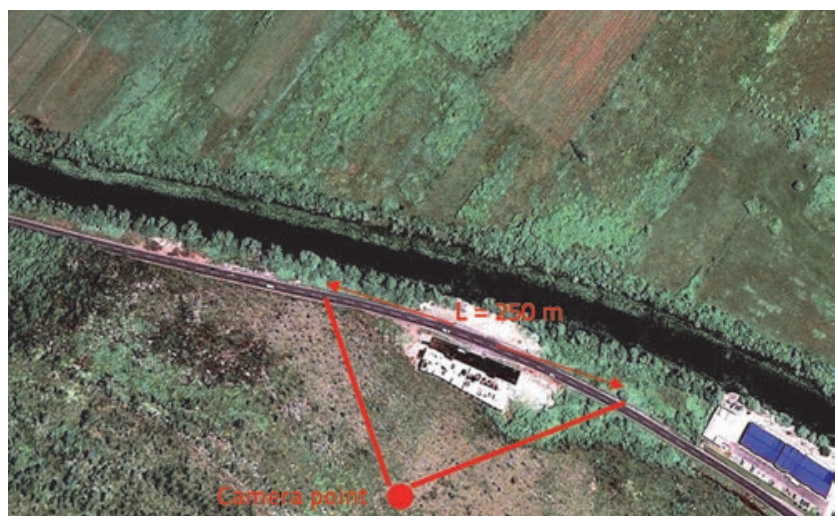

Figure 6. Section I with camera position and recording zone

\section{Section II}

This section is located along the Podgorica-Cetinje Motorway, as shown in Figure 7. The road is in a mild horizontal curve, with longitudinal grade of about $0.6 \%$. The roadway width is $2 \times 3.5$ $\mathrm{m}+2 \times 0.35$. Berms are $1.5 \mathrm{~m}$ in width. The road surface is in a good condition, without hair cracks. The road is in a cutting, and the cutting slopes are mildly inclined. The total length of the broken line is $400 \mathrm{~m}$ at this section. An additional slow lane ends $100 \mathrm{~m}$ before the start of the section. After the section, there is a mild curve where overtaking is not allowed. Before and after this section, the road grade is similar to the grade of the analysed section. The length of the road zone covered by the analysed video recording is $\mathrm{L}=250 \mathrm{~m}$.

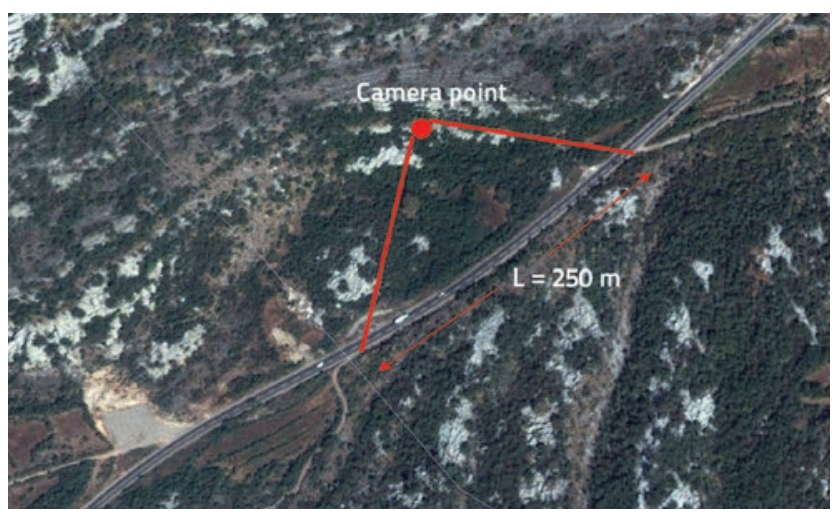

Figure 7. Section II with camera position and recording zone

\section{Section III}

This section is located along the Podgorica-Nikšić Motorway, as shown in Figure 8.

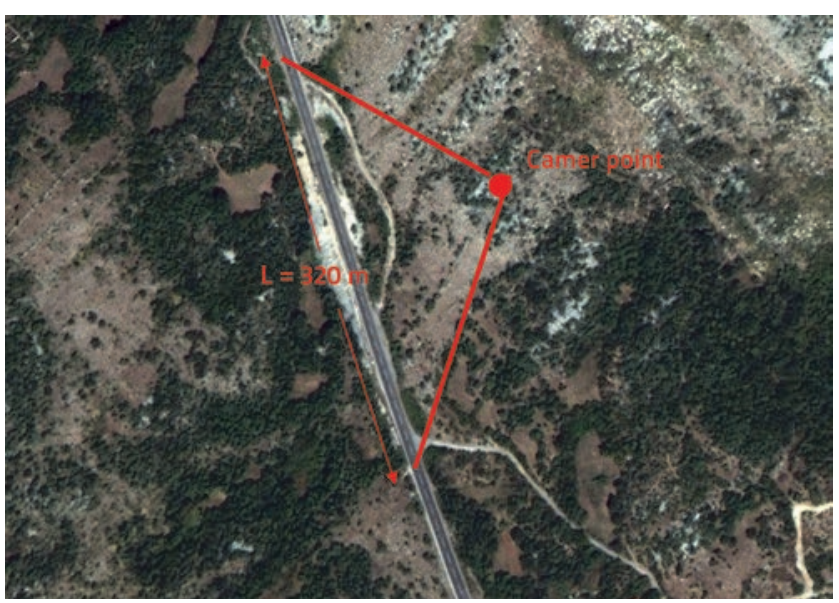

Figure 8. Section III with camera position and recording zone

At this section, the road in not in curve, and the longitudinal grade is $3.25 \%$. This longitudinal grade stretches for another $1.234 \mathrm{~m}$, and the section on which recording was conducted is at the end of the grade. The roadway width is $2 \times 3.5+2 \times 0.35 \mathrm{~m}$. Road is in a cutting. The cutting slope is mild, and the embankment slope is inclined at 1:1.5. Berms (shoulders) are $1.5 \mathrm{~m}$ in width. 
The road is in a good condition, without hair cracks or signs of damage. The total length of broken line is $600 \mathrm{~m}$ at this section. Before this section, the roadway is divided in a mild right-side curve by solid line and later, in the mild left-side curve, it is also divided by solid line. The road runs at constant upward grade, with an unchanged longitudinal grade. The length of the road zone covered by the analysed video recording is $L=320 \mathrm{~m}$ [18].

\section{Research results and discussion}

Parameters for every passing recorded at the studied road sections were determined by analysis of video recordings in line with the above described procedure. The analysis of results revealed speed values for passing and overtaken vehicles, distance between the queued vehicles at the beginning and the end of the passing distance, actual length of the passing distance, as well as duration of each part of the passing distance. In addition, the type and sort of passing vehicles and overtaken vehicles was differentiated in the scope of the database.

Figure 9.a shows passing distances for the sample of 203 passing actions for all types of vehicles that participated in the passing under real traffic flow conditions. Passing distances were classified by $10 \mathrm{~m}$ categories, and were then statistically analysed using the MiniTab program. Analysis results show that the measured passing distance values have a normal distribution, with the largest number of conducted passing actions in the range from $100 \mathrm{~m}$ to $110 \mathrm{~m}$, while $85 \%$ of passing distances ranged from $70 \mathrm{~m}$ to $130 \mathrm{~m}$. Further statistical analysis revealed that the mean passing distance value at the observed random sample is $103.1 \mathrm{~m}$, with the standard deviation of 25.14.

Figure 9.b shows the distribution of field measured distances, where the sample does not include vehicles exceeding the speed limit. Out of the total of 203 passing actions, 81 (representing $40 \%$ of the sample) were performed at the speed lower than the design speed, i.e., under the speed limit of $80 \mathrm{~km} / \mathrm{h}$. In these cases, when vehicles were passing at speeds equal to or lower than the design speed, an average length of the passing distance was about $95 \mathrm{~m}$, with the maximum of $165 \mathrm{~m}$, which is a slight difference when compared to the results obtained based on the total sample.

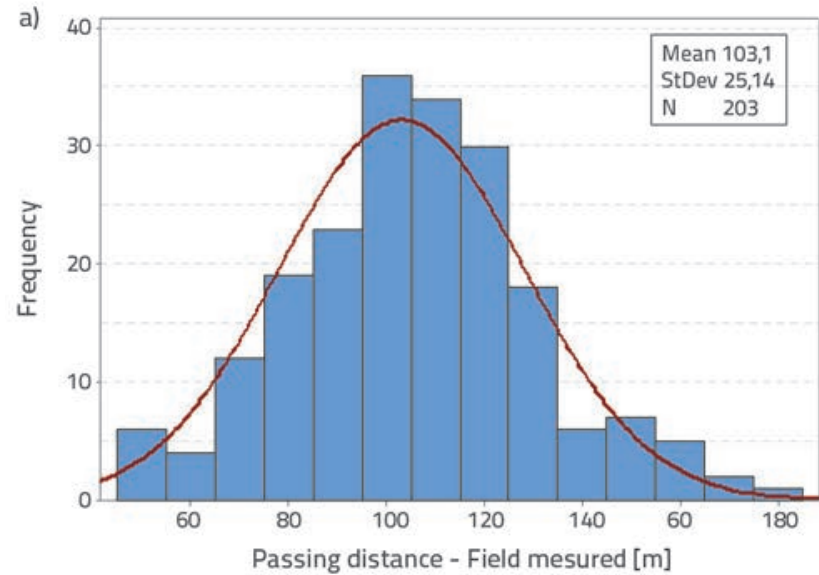

b)

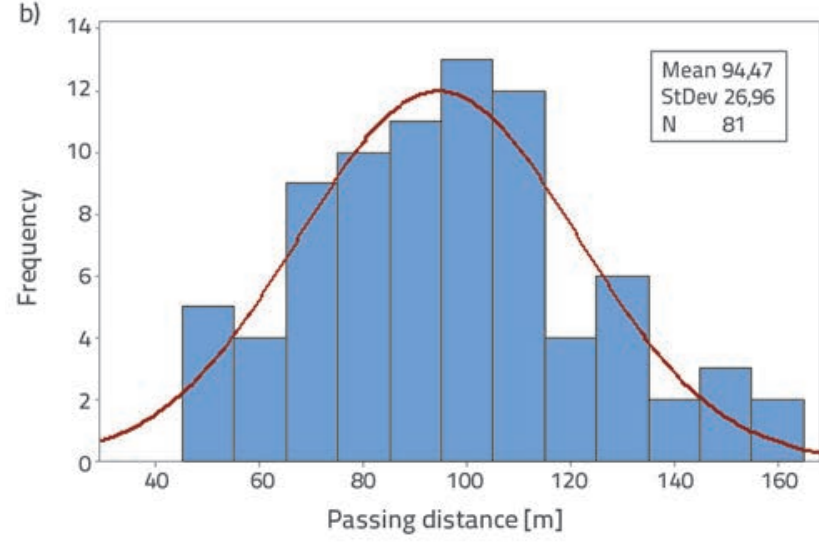

Figure 9. Distribution of passing distance field measurements: a) for all types of vehicles; b) for cases when passing vehicle speed is lower than design speed

Table 1. Passing distance in correlation with speed of overtaken vehicle

\begin{tabular}{|c|c|c|c|c|c|c|c|}
\hline \multirow{2}{*}{$\begin{array}{c}\text { Speed } \\
\text { of overtaken vehicle } \\
{[\mathrm{km} / \mathrm{h}]}\end{array}$} & \multirow{2}{*}{$\begin{array}{c}\text { Average speed of } \\
\text { overtaking vehicle } \\
{[\mathrm{km} / \mathrm{h}]}\end{array}$} & \multirow{2}{*}{$\begin{array}{c}\text { Time of } \\
\text { overtaking } \\
{[\mathrm{s}]}\end{array}$} & \multicolumn{4}{|c|}{$\begin{array}{l}\text { Overtaking distance } \\
{[\mathrm{m}]}\end{array}$} & \multirow{2}{*}{$\begin{array}{c}\text { The sample } \\
\text { size } \\
\text { N }\end{array}$} \\
\hline & & & Minimum & Maximum & Average & $85 \%$ & \\
\hline $10-20$ & 45,0 & 4,5 & 45 & 70 & 55 & 64 & 10 \\
\hline $20-30$ & 57,1 & 4,4 & 60 & 80 & 70 & 77 & 5 \\
\hline $30-40$ & 60,5 & 5,2 & 65 & 130 & 85 & 97 & 12 \\
\hline $40-50$ & 65,4 & 5,5 & 50 & 150 & 98 & 114 & 29 \\
\hline $50-60$ & 70,8 & 5,2 & 65 & 160 & 101 & 117 & 39 \\
\hline $60-70$ & 82,0 & 5,0 & 65 & 165 & 111 & 130 & 51 \\
\hline $70-80$ & 92,5 & 4,6 & 85 & 180 & 118 & 142 & 38 \\
\hline $80-90$ & 101,3 & 4,0 & 80 & 135 & 111 & 125 & 16 \\
\hline $90-100$ & 102,8 & 3,2 & 85 & 95 & 90 & 94 & 2 \\
\hline $100-110$ & 111,4 & 4,2 & 130 & 130 & 130 & 130 & 1 \\
\hline
\end{tabular}


The results obtained by further analysis show that the passing distance is not directly related to the speed of the overtaken vehicle. Table 1 shows the minimum, maximum, and mean passing distances generated under real traffic conditions on the sample of $\mathrm{N}$ vehicles, as related to the overtaking vehicle speed, overtaken vehicle speed, and the overtaking time. Speed categories of overtaken vehicles at the beginning of the overtaking action are given in the first column. The second column shows the average speed achieved by vehicles overtaking the vehicles from the corresponding first column group. The overtaking time $\left(t_{p}\right)$, shown in column 3 , is the time that elapses from the moment the vehicle starts overtaking and moves to the left, to the moment when it comes back to the right lane, i.e. to the position approximately parallel to the longitudinal axis.

In the above models, serving as basis for the overtaking sight distance determination, the overtaking distance is determined depending on the design speed. At the analysed sections, the design speed is $80 \mathrm{~km} / \mathrm{h}$ and, according to models [2] and [13], the adopted speed of the overtaken vehicle amounts to $65 \mathrm{~km} / \mathrm{h}$ at sections where the design speed is $80 \mathrm{~km} / \mathrm{h}$. The shadowed area in Table 1 represents values that could be adopted, according to the mentioned models, as overall design values for a road with the design speed of $80 \mathrm{~km} / \mathrm{h}$. Based on the analysis of the said models $[2,12,13]$, it can be concluded that there are significant differences in overtaking times, as shown in Table 2.

Table 2. Overtaking time according to analysed models

\begin{tabular}{|c|c|c|c|}
\hline Model & $\begin{array}{c}\text { ASSHATO } \\
\text { model }\end{array}$ & $\begin{array}{c}\text { Wang and } \\
\text { Cartmell } \\
\text { model }\end{array}$ & $\begin{array}{c}\text { Model used in } \\
\text { SEE countries }\end{array}$ \\
\hline $\begin{array}{c}\text { Overtaking } \\
\text { time }\end{array}$ & $10,7 \mathrm{~s}$ & $8,7 \mathrm{~s}$ & $10,0 \mathrm{~s}$ \\
\hline
\end{tabular}

According to the AASHTO model [2], the overtaking time represents the time required to travel the distance $d_{2}$ based on an average overtaking vehicle speed of $84,5 \mathrm{~km} / \mathrm{h}$, which almost coincides with an average speed of the overtaking vehicle, as defined in the research undertaken for the purposes of this paper. Based on the Wang and Cartel model, the overtaking time is the sum of times $T_{1^{\prime}} T_{2}$ and $T_{3^{\prime}}$ which is defined based on inputs adopted for the design speed of $80 \mathrm{~km} / \mathrm{h}$ [13].

In Table 2, the last column shows the overtaking time based on the models used in the South East Europe (SEE) for the same design speed [12].

Overtaking distances obtained from the models analysed in this paper are shown in Figure 10. The last column in the diagram represents the $85^{\text {th }}$ percentile of the overtaking distance as defined in the research conducted for the purposes of this paper, for the average overtaking speed of
$82,0 \mathrm{~km} / \mathrm{h}$ and for the speed of the overtaken vehicle ranging from 60 to $70 \mathrm{~km} / \mathrm{h}$.

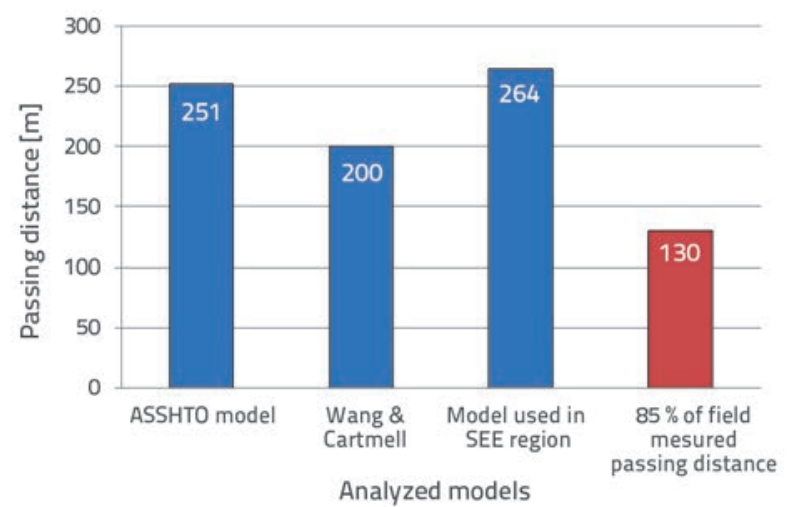

Figure 10. Passing distance according to analysed models, for design speed of $80 \mathrm{~km} / \mathrm{h}$ and research output values

Previous analyses have shown that significant differences exist between the passing distance as defined by study of the real traffic flow, and the passing time obtained based by means of theoretical models. These differences result from different input parameters that are used in the theoretical models, compared to the values of such parameters obtained in real traffic flow. This is primarily related to the passing time, which is significantly shorter in real traffic flow compared to theoretical models, and it results from the driver's behaviour and/or driving performance. It is assumed in theoretical models that the passing vehicle moves within the speed limit. The study of the real traffic flow has shown that about one-third of drivers starts passing at the speed higher than the speed limit [19]. In addition, during the passing manoeuvre, drivers constantly accelerate, which significantly reduces the passing time, resulting in lower passing distance. Only the AASHTO model takes into account the fact that vehicles are speeding up and this when defining a part of the passing distance, i.e. the distance passed during perception and reaction time, and during initial acceleration to the point of moving to the left lane. Other models ignore this fact, which is why the passing distance calculated in this way significantly exceeds values obtained in real traffic flow.

The analysis also included calculation of passing distances based on models $[2,12,13]$, using the passing time as defined in the scope of research performed for the purposes of this paper, as shown in Figure 11.

Results of the preceding analysis show that $85 \%$ of passing distances determined by analysis of the real traffic flow coincide with passing distances obtained according to the Wang and Cartmell model [13], and according to the model used in the $\mathrm{SEE}$ region [12]. Some discrepancies have however been noted in relation to the AASHTO model [2]. This points to the need to perform real traffic flow surveys under different road and traffic conditions. Changes in the driving-dynamic features of 
vehicles, and changes in road quality and signalisation, have resulted in changes relating to the behaviour and performance of drivers, and in reduction of passing distance, which is the basic element for calculating the passing sight distance.

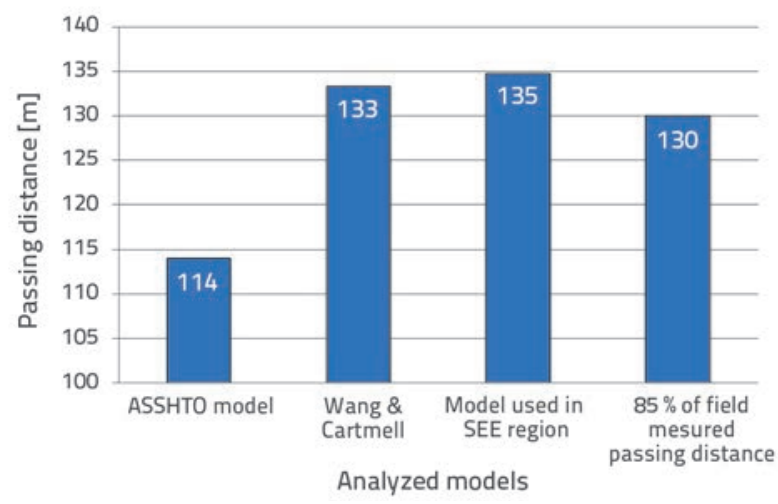

Figure 11. Passing distances defined based on analysed models and passing time $t_{p}$ for the design speed of $80 \mathrm{~km} / \mathrm{h}$ in correlation with the research output values

\section{Conclusion}

This paper is the result of the analysis of passing distance as conducted under real traffic flow conditions at three sections of the class 1 state roads in Montenegro. All three sections are two-lane roads intended for traffic in both directions, and their cross-sectional and horizontal alignment allows an undisturbed overtaking manoeuvre in both directions of travel. There are no special restrictions on these sections, and the survey was carried out under conditions of a real heterogeneous traffic flow. The real traffic flow was recorded with a broadband camera placed at an appropriate location, so as not to have any influence on the behaviour of drivers. The data analysis was performed by methods that enable high precision, repeated measurements, and verification of results.

The analysis of samples formed for this survey shows that there is a significant difference between the passing distance obtained by calculation according to internationally accepted theoretical models, and the passing distance obtained under real traffic flow conditions. Namely, the passing distance in real traffic flow is substantially lower than the passing distance obtained by calculations based on theoretical models.

Shorter passing distances are primarily due to shorter passing time in the real traffic flow, when compared to the passing time obtained in theoretical models.

If passing distances occurring under real traffic flow are taken into consideration, the required passing sight distance would be significantly lower, which would increase the allowed-overtaking zone, and improve the level of service. For this reason, this research should be expanded to cover the sections with different characteristics of horizontal geometry, and the analysis should include all parameters that are relevant in the process of defining the passing sight distance. In this way, conditions would be created for defining the model aimed at determining the passing sight distance in accordance with real traffic flow characteristics.

\section{REFERENCES}

[1] OECD, Safety Strategies for Rural Roads, Organisation for Economic Co-operation and Development, Paris, 1999.

[2] Transportation research board: NCHRP report 605 - Passing Sight Distance Criteria. Transportation research board of the National Academies, Washington D.C., 2008.

[3] Toledo, T., Haneen, F.: Passing behavior on two-lane highways. Transportation Research Part F, 13 (2010), pp. 355-364.

[4] Transportation Resarch Borard: Highway Capacity Manual (HCM) 2010, Transportation Resarch Borard, Washingthon D.C., 2011.

[5] Kuzović, Lj., Bogdanović, V.: Teorija prometnog toka, Fakultet tehničkih nauka, Novi Sad, 2010.

[6] A Policy on Geometric Design of Rural Highways, American Association of State Highway and Transportation Official, Washingthon D.C.,1954.

[7] A Policy on Geometric Design of Highways and Streets - Green Book", American Association of State Highway and Transportation Official, Washingthon D.C., 1984.

[8] Pravilnik o osnovnim uslovima koje javni putevi,njihovi elementi i objekti na njima moraju ispunjavati sa aspekta bezbjednosti prometa, Ministarstvo transporta i komunikacija Bosne i Hercegovine, "Službeni glasnik BiH" 6/06, Sarajevo, 2007.

[9] Pravilnik o osnovnim uvjetima kojima javne ceste izvan naselja njihovi elementi moraju udovoljavati sa stajališta sigurnosti prometa, Ministarstvo pomorstva, prometa i veza Republike Hrvatske, NN 110/01, Zagreb, 2001.
[10] Pravilnik o osnovnim uslovima koje javni putevi van naseljenih mesta i njihovi elementi moraju ispunjavati sa stanovišta bezbednosti prometa, Službeni list SFRJ 35/81-939, Beograd, 1981.

[11] Pravilnik o uslovima koje sa aspekta bezbednosti prometa moraju da ispunjavaju putni objekti i drugi elementi javnog puta, Ministarstvo za infrastrukturu RS, "Službeni glasnik RS" 50/2011, Beograd, 2011.

[12] Katanić, J., Anđus, V., Maletin, M.: Projektiranje cesta, četvrto izdanje, IRO "Građevinska knjiga" Beograd, Beograd, 1983.

[13] Wang, Y., Cartmell, M.: New Model for Passing Sight Distance, ASCE Journal of transportation engineering, 124 (1998), 6, pp. 536-545.

[14] Bogdanović, V., Ruškić, N., Papić Z., Simeunović, M.: The Research of Vehicle Acceleration at Signalized Intersections, Promet Traffic \& Transportation, Vol 25, pp. 33-42, 2013, Zagreb, Croatia.

[15] Bogdanović, V., Saulić, N., Ruškić, N., Ivanović, B., Ilin, V.: Analiza karakteristika vremenskog intervala sleđenja na semaforisanim raskrsnicama, Put i promet 59 (2013), 1, pp. 19-24.

[16] Bogdanović, V., Ruškić, N., Kulović, M., Han, L.:TowardaCapacity Analysis Procedure for Nonstandard Two-Way Stop-Controlled Intersections, Transportation Research Record: Journal of the Transportation Research Board, 2395 (2013), pp. 132-138., doi: 10.3141/2395-15

[17] Glavni projekat puta Titograd-Danilovgrad, Republički fond za puteve Titograd,1973.

[18] Glavni projekat Titograd-Nikšić, Centroprojekt Beograd, 1973.

[19] Ivanović, B., Basarić, V., Garunović, N., Mitrović, J., Saulić, N.: Research of speeds in overpassing, Put i promet, 60 (2014), 1, 39-44. 